OPEN ACCESS

Edited by:

Dongyan Liu,

East China Normal University, China

Reviewed by: Vincent M. P. Bouchet, Université de Lille, France Charlotte LeKieffre,

CEA Grenoble, France

${ }^{*}$ Correspondence: Michael Lintner michael.lintner@univie.ac.at

Specialty section: This article was submitted to Marine Ecosystem Ecology,

a section of the journal

Frontiers in Marine Science

Received: 16 September 2021 Accepted: 27 October 2021 Published: 18 November 2021

Citation:

Lintner $M$, Lintner B, Wanek W Schmidt S, Keul N and Heinz P (2021) Assimilation of Particular Organic Matter and Dissolved Organic or Inorganic Compounds by

Cribroelphidium selseyense (Foraminifera).

Front. Mar. Sci. 8:778148. doi: 10.3389/fmars.2021.778148

\section{Assimilation of Particular Organic Matter and Dissolved Organic or Inorganic Compounds by Cribroelphidium selseyense (Foraminifera)}

\author{
Michael Lintner ${ }^{1 *}$, Bianca Lintner ${ }^{1}$, Wolfgang Wanek ${ }^{2}$, Sarina Schmidt ${ }^{3}$, Nina Keul ${ }^{4}$ and \\ Petra Heinz ${ }^{1}$ \\ ${ }^{1}$ Department of Palaeontology, University of Vienna, Vienna, Austria, ${ }^{2}$ Division of Terrestrial Ecosystem Research, \\ Department of Microbiology and Ecosystem Science, Center of Microbiology and Environmental Systems Science, University \\ of Vienna, Vienna, Austria, ${ }^{3}$ Geomar, Helmholz-Zentrum für Ozeanforschung Kiel, Ozeanzirkulation und Klimadynamik, Kiel, \\ Germany, ${ }^{4}$ Department of Marine Climate Research, Christian-Albrechts-University of Kiel, Kiel, Germany
}

Marine carbon and nitrogen processing through microorganisms' metabolism is an important aspect of the global element cycles. For that purpose, we used foraminifera to analyze the element turnover with different algae food sources. In the Baltic Sea, benthic foraminifera are quite common and therefore it is important to understand their metabolism. Especially, Cribroelphidium selseyense, also occurring in the Baltic Sea, has often been used for laboratory feeding experiments to test their effect on carbon or nitrogen turnover. Therefore, foraminifera were collected from the Kiel Fjord and fed with six different algal species in two qualities (freeze-dried algae vs. fresh algae, all ${ }^{13} \mathrm{C}$ - and ${ }^{15} \mathrm{~N}$-labeled). Also, labeled dissolved inorganic $\mathrm{C}$ and $\mathrm{N}$ compounds and glucose were offered to the foraminifera to test direct assimilation of dissolved compounds (carbon and nitrogen) from the water column. Our experiments showed that after 15 days of incubation, there were highly significant differences in isotope labeling in foraminifera fed with fresh algae and dry algae, depending on algal species. Further, different algal species led to different ${ }^{13} \mathrm{C}$ and ${ }^{15} \mathrm{~N}$ enrichment in the studied foraminifera, highlighting a feeding preference for one diatom species and an Eustigmatophyte. A significant carbon assimilation from $\mathrm{HCO}_{3}{ }^{-}$was observed after 7 days of incubation. The $\mathrm{N}$ assimilation from $\mathrm{NH}_{4}{ }^{+}$was significantly higher than for $\mathrm{NO}_{3}{ }^{-}$as an inorganic $\mathrm{N}$ source. The uptake of glucose showed a lag phase, which was often observed during past experiments, where foraminifera were in a steady state and showed no food uptake at regular intervals. These results highlight the importance of food quality on the feeding behavior and metabolic pathways for further studies of foraminiferal nutrition and nutrient cycling.

Keywords: foraminifera (benthic), feeding experiments, different food supplies, organic food uptake, Inorganic compound uptake 


\section{INTRODUCTION}

Foraminifera are marine unicellular protists (rhizaria), which play an important role in marine element cycles (e.g., Gooday et al., 1992; Cesborn et al., 2017; Bird et al., 2020). They feed on phytoplankton (Austin et al., 2005), bacteria (Schmidt et al., 2021), even on metazoans (Chronopoulou et al., 2019) and are transferring energy in form of organic matter to a higher trophic level (e.g., Azam et al., 1983; Beringer et al., 1991; Van Oevelen et al., 2006). In previous laboratory observations, it turned out that a very common foraminifera (Ammonia tepida) act as a carnivore and predate on nematodes, artemia, copepods and on larval gastropods (Suhr et al., 2008; Dupuy et al., 2010). In past feeding experiments, the uptake of diatoms, dinoflagellates, chlorophytes, chrysophytes, cyanophytes, bacteria and yeast by different foraminifera were investigated (Lee et al., 1966). They observed, that dinoflagellates, chrysophytes, most bacteria and also yeast were not digested by foraminifera, whereas in contrast the other algae were digested in large quantities. Due to the high number of foraminifera in marine habitats and their contribution to the uptake of phytodetritus, foraminifera are important for marine carbon and nitrogen cycles (e.g., Altenbach, 1992). The food uptake of foraminifera depends on several parameters. Ecological parameters like food supply and food quality (Lee et al., 1966) as well as changes in physical parameters like temperature (Wukovits et al., 2017) or salinity (Lintner et al., 2020) lead to a different feeding behavior and changes in carbon and nitrogen fluxes via foraminifera. With these experiments, it could be shown that common foraminifera from the mudflats (Ammonia tepida and Haynesina germanica) can deal with shifts in temperature between 20 and $30^{\circ} \mathrm{C}$ but have their optimum at $25^{\circ} \mathrm{C}$ (Wukovits et al., 2017). In case of salinity changes it seems, that $A$. tepida felt more comfortable at higher salinities (37 PSU) than $H$. germanica, which have their highest metabolic activity at 24 PSU (Lintner et al., 2020). Both species showed a very low metabolic activity at low salinities (11 PSU). In contrast, the foraminifera Cribroelphidium selseyense from the Baltic Sea can cope with low salinities (15 PSU) much better than with an increase of the salt content of the seawater (25 PSU) (Lintner et al., 2021a). For all these experiments the green algae Dunaliella tertiolecta was used as a food source. It could be observed, that the ingested amount of food by $C$. selseyense was much lower than of the other species (A. tepida and $H$. germanica) and it is assumed, that these algae is not a preferred food source of this foraminifera (Lintner et al., 2021a). Laboratory experiments with Ammonia tepida showed that the green algae Dunaliella parva was a suitable food source for these foraminifera (Lee et al., 1961), however, Haynesina germanica preferred diatoms as a food source (Austin et al., 2005). In contrast, the preferred algae food source of $C$. selseyense has never been investigated. This is of particular interest, when analyzing the effect of environmental parameters on $C$. selseyense, because a higher food uptake of foraminifera can lead to a better interpretation of the results from such feeding experiments. Furthermore, dissolved heavy metal concentrations (Lintner et al., 2021b) or the light regime (Lintner et al., 2021a) can affect the feeding and the metabolic activity of foraminifera. In this case, it could be shown, that an enrichment of $\mathrm{Cu}$ led to a dramatic increase of the food uptake of $C$. selseyense, whereas $\mathrm{Zn}$ or $\mathrm{Pb}$ does not significantly affect the metabolisms of this foraminifera (even for $\mathrm{Zn}$ a trend was observed) (Lintner et al., 2021b). Additionally, foraminifera show different chloroplast uptake ratios (kleptoplastidy) with different algal diets (Correia and Lee, 2000).

In this study the food preference (preferred algae) of the foraminiferal species Cribroelphidium selseyense was tested, due to the high relevance for $\mathrm{C}$ or $\mathrm{N}$ processing. This species is also known as Elphidium selseyense, which is part of the species complex Elphidium excavatum (Darling et al., 2016). According to Darling et al. (2016) the species C. selseyense corresponds to the species E. excavatum S5. Generally, Elphidium (Cribroelphidium) is optimally suited for investigations in the Kiel Fjord, because this genus can account for over $90 \%$ of the foraminiferal assemblages there (Schönfeld and Numberger, 2007). Therefore, we tested the $\mathrm{C}$ and $\mathrm{N}$ uptake rates of C. selseyense for 6 different algal species. The algae were offered either as freeze-dried or as fresh material to investigate feeding preferences between fresh and dried algal diet. Finally, we tested the incorporation of inorganic and organic $\mathrm{C}$ and of inorganic $\mathrm{N}$ (nitrate vs. ammonium) of these foraminifera. All these results will help to understand the feeding behavior of this foraminifera. This study will lead to a better understanding of the feeding behavior of foraminifera and should optimize further feeding experiments with $C$. selseyense by selecting a preferred food source (algae) for them.

\section{MATERIALS AND METHODS}

\section{Sampling Site}

Samples for this study were collected in Kiel Fjord in northern Germany. This Fjord has a length of $9.5 \mathrm{~km}$ and is about 250 $\mathrm{m}$ wide in the inner Fjord and $7.5 \mathrm{~km}$ in the outer Fjord (Nikulina et al., 2007). Water depths range from 10 to $12 \mathrm{~m}$ in the inner Fjord and up to $20 \mathrm{~m}$ in the outer part of the Fjord. Temperature and salinity are relatively constant at any water depth (Schwarzer and Themann, 2003). In summer, the water masses are stratified, the bottom water with $12^{\circ} \mathrm{C}$ and a salinity of 21 practical salinity units (PSU) in contrast to surface waters with $16^{\circ} \mathrm{C}$ and a salinity of $14 \mathrm{PSU}$ (Polovodova and Schönfeld, 2008). In the southeast of the inner Fjord, the Schwentine river supplies fresh water, which causes a lower salinity of the water in this area. Due to the high eutrophication of the Kiel Fjord in the last 70 years, an increase of $\mathrm{Cu}$ or $\mathrm{Zn}$ in fishes and mollusks was observed (ter Jung, 1992; Senocak, 1995). Experiments with C. selseyense showed that increased metal concentrations, especially $\mathrm{Cu}$, lead to a decrease of feeding and metabolic activity (Lintner et al., 2021a). Further, the Kiel Fjord is enriched in organic $\mathrm{C}$ and nutrients, originating from Kiel city and the surrounding industry (Gerlach, 1984). This high input of nutrients results in a high primary production, which leads to an increased production of phytodetritus and therefore a high food availability for foraminifera in that area (Gerlach, 1990). 


\section{Sampling of Foraminifera}

The sediment samples with living foraminifera were collected from the Kiel Fjord in northern Germany on 1st and 2nd of July 2020. The samples were taken with a box corer on the research vessel F. S. ALKOR from $12.3 \mathrm{~m}$ water depth at $\mathrm{N} 54^{\circ} 25.255^{\prime}$ and E $10^{\circ} 12.315^{\prime}$. The surface water temperature was $14.0^{\circ} \mathrm{C}$ and the salinity was 13.6 PSU. On board of the F. S. ALKOR the first $5 \mathrm{~cm}$ of the sediment were wet sieved with Baltic seawater though a $125 \mu \mathrm{m}$ sieve. The sediments were kept in a storage box, which was filled with seawater from the sampling site and stored at constant $20^{\circ} \mathrm{C}$ in the laboratory at the Geomar Helmholtz Centre for Ocean Research Kiel, Germany.

\section{Preparation of Labeled Food Sources}

Different types of food sources were used in culturing experiments. First, different algae (Chaetoceros calcitrans, Dunaliella tertiolecta, Isochrysis galbana, Leyanella arenaria, Nannochloropsis salina, and Phaeodactylum tricornutum) were offered to the foraminifera as freeze-dried algae or as fresh algae. The algae C. calcitrans, $L$. arenaria, and $P$. tricornutum are diatomophyceae, $D$. tertiolecta is a green alga, $N$. salina an Eustigmatophyte and I. galbana a Haptophyte. All algae, except of $L$. arenaria and D. tertiolecta are common in the Baltic Sea. These two algae (L. arenaria and D. tertiolecta) were also tested, because they are very common algae in feeding experiments and have been used several times with foraminifera (e.g., Lintner et al., 2021b). Further, dissolved inorganic compounds $\left(\mathrm{CO}_{3}{ }^{2-}\right.$, $\mathrm{NH}_{4}{ }^{+}$or $\mathrm{NO}^{3-}$ ) as well as glucose were used as dissolved $\mathrm{C}$ or $\mathrm{N}$ sources. Throughout this manuscript we define the experiment with glucose as glucose feeding experiments. The experiments with algae are termed algal feeding experiments (fresh or dried algae).

- Dried algae: for this kind of food source the algae were incubated in a f/2 nutrient medium after Guillard and Ryther (1962). This medium was enriched with the isotopes ${ }^{13} \mathrm{C}$ and ${ }^{15} \mathrm{~N}$ by adding $1.5 \mathrm{mmol} \mathrm{L}{ }^{-1} \mathrm{NaH}^{13} \mathrm{CO}_{3}$ and $0.44 \mathrm{mmol} \mathrm{L}^{-1} \mathrm{Na}^{15} \mathrm{NO}_{3}$. The different algal cultures were kept at $20^{\circ} \mathrm{C}$ and a light/dark rhythm of $16: 8 \mathrm{~h}$ and were harvested, when the culture showed a strong green or brown (depending on algae) color, indicating peak biomass. Thereafter the algal cultures were centrifuged at $800 \times \mathrm{g}$ for $10 \mathrm{~min}$. Algal pellets were washed three times with sterile seawater and were centrifuged after each washing step. To produce an algal powder, the pellets were shock frozen in liquid nitrogen and afterward lyophilized for 3 days at 0.180 mbar. The dried algae were stored in a dark and dry place in order to retain a high food quality.

- Fresh algae: again, a f/2 nutrient medium after Guillard and Ryther (1962) was prepared and enriched as described above with ${ }^{13} \mathrm{C}$ and ${ }^{15} \mathrm{~N} .10 \mathrm{ml}$ algal culture was added to $40 \mathrm{ml}$ nutrient medium. These cultures were incubated at $20^{\circ} \mathrm{C}$ and a light/dark rhythm of $16: 8 \mathrm{~h}$ for 3 weeks. After this time the algal cultures had their characteristic color (intense green or brown, depending on the algae) and were ready to be offered to foraminifera as fresh food source.

- Inorganic/organic compounds: the substances $\left(\mathrm{Na}^{13} \mathrm{HCO}_{3}\right.$, ${ }^{15} \mathrm{NH}_{4} \mathrm{Cl}, \mathrm{Na}^{15} \mathrm{NO}_{3}$, and ${ }^{13} \mathrm{C}$ labeled D-glucose) were added separately into sterile filtered seawater from the sampling site. Finally, a concentration of $0.1 \mathrm{~mol} \mathrm{~L}^{-1}$ $\mathrm{H}^{13} \mathrm{CO}_{3}{ }^{2-},{ }^{15} \mathrm{NH}_{4}{ }^{+},{ }^{15} \mathrm{NO}_{3}{ }^{-}$, and ${ }^{13} \mathrm{C}$-glucose was established in separate crystallization dishes.

\section{Culturing Experiments}

In order to test the $\mathrm{C}$ and $\mathrm{N}$ uptake, three different culturing experiments were performed:

1) Feeding with dried algae

2) Feeding with fresh algae

3) Uptake of dissolved compounds

Total experimental duration was 15 days in total. At six different points in time (after 1, 3, 5, 7, 10, 15 days) foraminifera were harvested in triplicates: each triplicate consisted of a $250 \mathrm{ml}$ crystallization dish filled with $250 \mathrm{ml}$ sterile filtered seawater (pore size: $0.45 \mu \mathrm{m}$ ) from the sampling site, in which 20 foraminifera $(C$. selseyense $>150 \mu \mathrm{m}$ ) were placed. This way it was ensured that a final dry mass of cytoplasm between 1 and $2 \mathrm{mg}$ could be obtained for each triplicate. For these experiments only foraminifera were used which were fully filled with brownish cytoplasm, indicating a healthy individual. All selected foraminifera were investigated using PAM (chlorophyll fluorescence imaging-Imaging PAM Microscopy VersionWalz $\mathrm{GmbH}$ ) to clarify, that this specimen does not contain any kleptoplasts or photoactive chloroplasts before the experiments started. Between sampling of the foraminifera from the Baltic Sea and starting the experiments, maximum 2 days passed. At the end of the experiments all individuals showed the same intensive brownish color, which means that all individuals were alive during the whole experiment. Additionally, untreated (not fed) foraminifera (triplicate to each 20 specimens) were taken from the main culture to obtain the natural abundance of ${ }^{13} \mathrm{C}$ and ${ }^{15} \mathrm{~N}$.

Feeding with dried algae: $5 \mathrm{mg}$ of lyophilized algal powder were added to the crystallization dishes for each of the 6 tested algal species. Each alga was added to separate dishes. Even after 15 days algal powder was present at the bottom of the dishes, indicating that there was enough food available during the whole experiment.

Feeding with fresh algae: $20 \mathrm{ml}$ of each algal culture were added to the crystallization dishes for each of the 6 tested algal species. Each alga was added to separate dishes.

Uptake of dissolved compounds: for these experiments the above-described enriched sea water solution was used for culturing.

After adding the respective algae or organic/inorganic $\mathrm{C}$ or $\mathrm{N}$ source, the dishes were closed with a parafilm to avoid evaporation during the experimental period. The experiments were run in an incubator at $18^{\circ} \mathrm{C}$ and a light dark rhythm of $16: 8 \mathrm{~h}$. At the end of the experiments the foraminifera were removed from the crystallization dishes and were cleaned in a separate dish with sterile filtered seawater. We removed all adhering algal particles from the foraminifera to avoid biases in the isotopic measurements. After that the foraminifera were flush washed with distilled water to remove the saltwater and to avoid 
mass (weighing) errors due to evaporation salts. This part had to be done very quickly, in order to avoid lysing the cells and possibly having a loss of cytoplasmic $\mathrm{C}$ or $\mathrm{N}$ during this washing step. Further information is described and discussed in Lintner et al. (2020).

Afterward, foraminifera were transferred into tin capsules ( $\mathrm{Sn}$ 99.9\%, IVA Analysetechnik GmbH \& Co. KG) and air dried for 3 days. Then $2 \times 5 \mu \mathrm{HCl}(4 \%)$ were added to dissolve the calcite tests. Finally, the samples were dried for 3 days at $60^{\circ} \mathrm{C}$ and were weighed to the nearest hundredth of milligram. The measurement of foraminiferal and algal $\mathrm{C}$ and $\mathrm{N}$ content and their isotope ratios $\left({ }^{13} \mathrm{C}:{ }^{12} \mathrm{C},{ }^{15} \mathrm{~N}:{ }^{14} \mathrm{~N}\right)$ were carried out at the Stable Isotope Laboratory for Environmental Research (SILVER) at the University of Vienna. Therefore, an isotope ratio mass spectrometer (IRMS, Delta ${ }^{\text {PLUS }}$ ) coupled by a ConFlo III interface to an elemental analyzer (EA 1110, all Thermo Finnigan) were used. The calculation of the incorporated amount of isotopically labeled $\mathrm{C}$ and $\mathrm{N}$ and the amount of phytodetrital $\mathrm{C}(=\mathrm{pC})$ and $\mathrm{N}$ $(=\mathrm{pN})$ uptake is described in detail in Lintner et al. (2020). The amount of organic and inorganic $\mathrm{C}$ and $\mathrm{N}$ uptake (IC, IN) were calculated analogously.

\section{Statistics}

The main effects of food source and time on $\mathrm{pC}, \mathrm{pN}$ and IC and IN as well as of dried vs. fresh algae and time on $\mathrm{pC}$ and $\mathrm{pN}$ were tested using analysis of variance (ANOVA, 95.0\% confidence intervals, $\alpha=0.05$, all data following normal distribution following Shapiro Wilkins test), followed by Tukey HSD tests. The statistical tests were performed using Statgraphics Centurion XVI. Graphically, the data were plotted in x-y graphs or box blots, where the mean values are from $n=3$ replicates, with $2 \sigma$ error bars for the standard deviation.

\section{RESULTS}

\section{Feeding With Dried Algae}

Two-way ANOVA showed a highly significant difference between the $\mathrm{C}$ uptake of different algal food sources $(p<0.001)$, with time $(p=0.017)$, and their interaction $(p<0.001)$. Also, the $\mathrm{N}$ uptake was highly significant different between the used food sources $(p<0.001)$, time $(p<0.001)$ and their interaction $(p<0.001)$.
A detailed description (results from the Tukey HSD test) of the various food sources is given in Appendix.

The $\mathrm{C}$ and $\mathrm{N}$ uptake of different food sources is shown in Figure 1. With time the food uptake differs significantly within one food source (e.g., uptake from N. salina was high at day 1 and 3, decreased sharply until day 10 and increased again until day 15). Such trends cannot be interpreted here, but it can be observed, that some algae are more preferable than others, because they show higher uptakes at every day of the experiment (e.g., uptake of P. tricornutum was always higher than of I. galbana). Considering C uptake of C. selseyense two algae (D. tertiolecta and I. galbana) were significantly $(p<0.001)$ less preferred than the others. This trend can be seen during the whole experiment (day 1 up to day 15). In contrast, the $\mathrm{N}$ uptake from a diet with $D$. tertiolecta was highest, the longer the experiment was run. Nitrogen uptake from different food sources was already significantly different after day $1(p=0.041)$. After day 5 , the uptake of $\mathrm{N}$ was lower from a diet with $N$. salina or $L$. arenaria in comparison to other algae. For longer durations ( $>7$ days) $\mathrm{N}$ uptake was highest $(p<0.001)$ from a diet of $D$. tertiolecta or P. tricornutum.

\section{Feeding With Fresh Algae}

For a fresh algal diet $\mathrm{C}$ uptake was significantly different, when considering time $(p=0.003)$ and food source as factors $(p<0.001)$. Nitrogen uptake showed a similar pattern, with significant effects of time $(p=0.02)$ and food source $(p<0.001)$. These experiments were run for 1 and 3 days, after that time the isotopic value of the algae changes too much and it is not further possible to measure reliably the uptake of food.

The $\mathrm{C}$ uptake from a diet of fresh algae (Figure 2) after 1 day were highest for C. calcitrans and lowest for I. galbana. After 3 days the highest $\mathrm{C}$ uptake was observed again from a diet of C. calcitrans and the second highest from a diet of $L$. arenaria. The lowest $\mathrm{C}$ uptake after 3 days was again from a diet of D. tertiolecta and I. galbana. Nitrogen uptake (Figure 2) after 1 day was highest from a diet of $C$. calcitrans and D. tertiolecta. After 3 days the $\mathrm{N}$ uptake pattern was quite similar to the pattern of $\mathrm{C}$ uptake. The highest amount of $\mathrm{N}$ was taken up from a diet of C. calcitrans and L. arenaria.
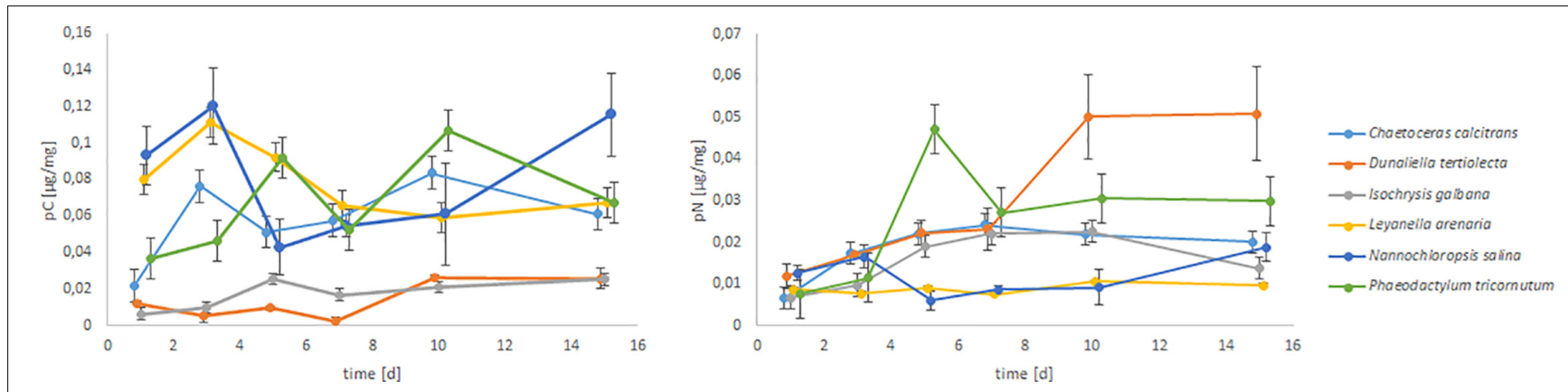

FIGURE 1 | C and N uptake of different food sources (dried algae) by C. selseyense. The datapoints are calculated from $n=3$ replicates and the error bars indicate the standard deviation. 


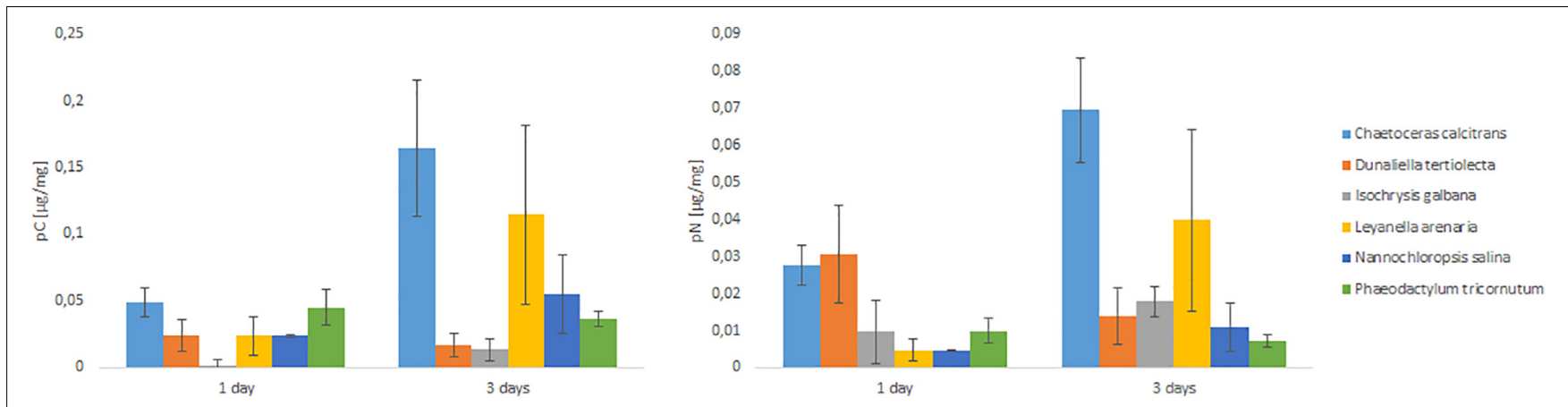

FIGURE 2 | C and N uptake of different food sources (fresh algae) by $\mathrm{C}$. selseyense. The datapoints are calculated from $n=3$ replicates and the error bars indicate the standard deviation.

\section{Feeding Preferences for Dried vs. Fresh Algae}

Three-way ANOVA for the effects of algal species, condition (dried vs. fresh algae) and time (1 and days), including their interactions showed the following: The carbon uptake depends significantly on tested algal species $(p<0.001)$ and time $(p<0.001)$ but not on condition (dried vs. fresh algae) $(p=0.596)$. When comparing $C$ uptake (Figure 3A) after 1 day, we found a higher $C$ uptake of fresh vs. dried algae when foraminifera were fed with $C$. calcitrans $(p=0.017)$, while foraminifera preferred dried algae over fresh algae when fed with L. arenaria $(p=0.044)$ or $N$. salina $(p=0.002)$ at this time point, and for other tested algae showed no preference. After 3 days the $\mathrm{C}$ uptake pattern changed (Figure 3B). Again, a fresh algal diet of C. calcitrans $(p=0.051)$ and D. tertiolecta $(p=0.102)$ was preferred, although uptake of $D$. tertiolecta was generally very low, while dried algal diet was only preferred when fed with N. salina $(p=0.034)$.

In contrast, nitrogen uptake was significant different in algal species $(p=0.001)$, time $(p=0.008)$ and condition $(p=0.003)$. When comparing $\mathrm{N}$ uptake, $\mathrm{N}$ uptake of fresh algae (Figure 3C) was significantly higher from a diet of C. calcitrans or D. tertiolecta $(p=0.042)$, while dried algae were only preferred from N. salina. After 3 days (Figure 3D) a higher $\mathrm{N}$ uptake was observed from a diet of fresh C. calictrans, I. galbana, and L. arenaria $(p=0.034)$, while dried algae were not preferred from any other algal species.

\section{Uptake of Organic or Inorganic Compounds}

For these experiments only dissolved compounds were added into the seawater (no algae) and therefore, we calculated the incorporated amount of isotopically labeled carbon or nitrogen. The statistical evaluation showed for all tested compounds $\left({ }^{13} \mathrm{CO}_{3}{ }^{2-},{ }^{15} \mathrm{NH}_{4}{ }^{+},{ }^{15} \mathrm{NO}_{3}{ }^{-}\right.$, and ${ }^{13} \mathrm{C}$ via glucose $)$ that $\mathrm{C}$ and $\mathrm{N}$ uptake increased significantly $(p<0.001)$ with time.

The $\mathrm{C}$ uptake via $\mathrm{CO}_{3}{ }^{2-}$ was very low until day 7 , but after day 7 the uptake increased very fast (Figure 4). The incorporated amount of $\mathrm{C}$ from glucose showed a more stepwise pattern. At day 1 and 3 the incorporated amount was very low, then increased sharply and showed a steady state from day 5 to day 10 , when it again strongly increased until day 15 .

Two-way ANOVA showed a highly significant $(p<0.001)$ difference of the $\mathrm{N}$ uptake from different inorganic $\mathrm{N}$ sources. A multiple range test (Tukey HSD test) confirmed this statement and divided the $\mathrm{N}$ uptake from ${ }^{15} \mathrm{NH}_{4}{ }^{+}$to ${ }^{15} \mathrm{NO}_{3}{ }^{-}$into two different homogeneous groups (Figure 4). Uptake of $\mathrm{N}$ from $\mathrm{NH}_{4}{ }^{+}$was generally higher $(p<0.001)$ during the whole experiment compared to $\mathrm{N}$ uptake from $\mathrm{NO}^{3-}$. The $\mathrm{N}$ uptake from $\mathrm{NO}_{3}{ }^{-}$was very low, but increased after 10 days. In contrast, $\mathrm{N}$ uptake from $\mathrm{NH}_{4}{ }^{+}$increased steadily (polynomially) with time $\left(r^{2}=0.98\right.$; Figure 5).

\section{DISCUSSION}

\section{Preference for Different Algal Species as Food Source}

Foraminifera feed on phytodetritus and prefer microhabitats where they can find their optimal food source (Linke and Lutze, 1993). Our results show that the food uptake of C. selseyense strongly depends on the offered food source (Figure 1). Chaetoceros calcitrans is a marine diatom occurring naturally in the Baltic Sea (Tantanasarit et al., 2012). The uptake (based on $\mathrm{pC}$ ) of these algae by $C$. selseyense was intermediate in a dried form, in comparison to other offered algae. On the other hand, C. selseyense preferred this species in a fresh algal diet. A possible explanation could be the presence of exopolymer particles, which are produced by C. calcitrans (Corzo et al., 2000) and which may get lost during the lyophilization process. For the other here tested algal species it is not clear, if they also are able to produce exopolymer particles. These particles are generally highly abundant in the ocean and can be used as an additional food source for many organisms (e.g., Shimeta, 1993). Additionally, C. calcitrans is well known for containing a high amount of cellular carbohydrates (Myklestad and Haug, 1972), which provide foraminifera a high energy feed source.

Dunaliella tertiolecta, a green alga, has often been used in past feeding experiments with foraminifera (e.g., Lintner et al., 2020), but does not naturally occur in the Baltic Sea. Previous experiments showed that $D$. tertiolecta was a preferred food 

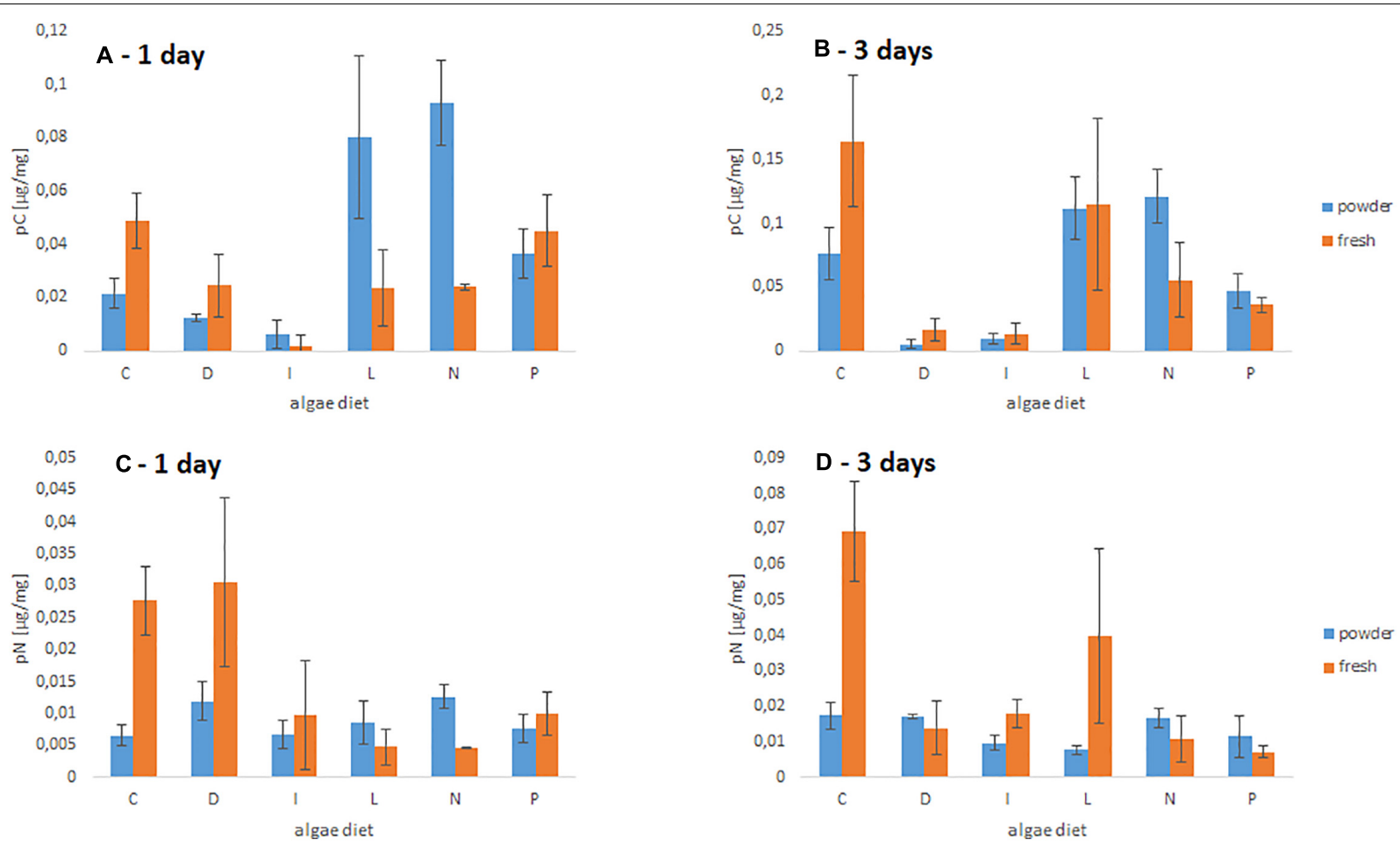

FIGURE 3 | C and N uptake of dried and fresh algal food sources by C. selseyense. The letters on x-axis are representing: C, Chaetoceros calcitrans; D, Dunaliella tertiolecta; I, Isochrysis galbana; L, Leyanella arenaria; N, Nannochloropsis salina; P, Phaeodactylum tricornutum. The datapoints were calculated from $n=3$ replicates and the error bars indicate the standard deviation. The box plots $(\mathbf{A}, \mathbf{C})$ represent the uptake of $\mathrm{C}$ and $\mathrm{N}$ after 1 day, $(\mathbf{B}, \mathbf{D})$ show the uptake after 3 days.
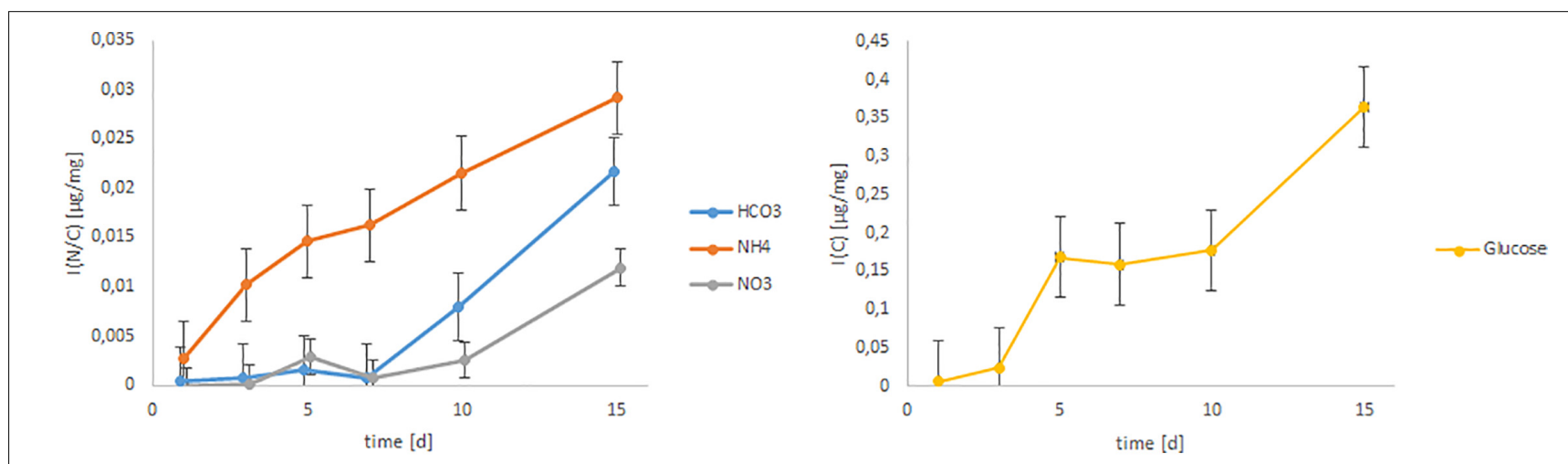

FIGURE 4 | Incorporated amount of ${ }^{15} \mathrm{~N}$ or ${ }^{13} \mathrm{C}$ from bicarbonate, glucose, ammonium and nitrate over time. The datapoints were calculated from $n=3$ replicates and the error bars indicate the standard deviation.

source for Ammonia tepida (Lee et al., 1961), which is also a common species in the Baltic Sea. This observation coincides with that of Lee et al. (1961) who found that the green algae D. parva especially stimulates the pseudopodal activity A. tepida. In parallel the uptake of $D$. tertiolecta by Haynesina germanica was tested, which is a closely related species to $C$. selseyense (Correia and Lee, 2000). It was shown that these algae were also not a preferred food source for $H$. germanica. Based on the results from our study here we can assume that $D$. tertiolecta is also not a preferred food source for C. selseyense. Especially a fresh $D$. tertiolecta diet was not favored in contrast to that of other offered algae. To analyze the food uptake of $C$. selseyense at different salt concentrations we also offered $D$. tertiolecta (also $5 \mathrm{mg}$ freeze-dried algae per dish) in past experiments as a food source and observed a $\mathrm{C}$ uptake between 0.04 and $0.1 \mu \mathrm{g} / \mathrm{mg}$ and an $\mathrm{N}$ uptake of $0.02-0.06 \mu \mathrm{g} / \mathrm{mg}$ after 15 days (Lintner et al., 2021b). In the study here we observe a C uptake of approximately $0.02 \mu \mathrm{g} / \mathrm{mg}$ and an $\mathrm{N}$ uptake of $0.01-$ $0.05 \mu \mathrm{g} / \mathrm{mg}$. Nitrogen incorporation was relatively similar in these two studies, but $\mathrm{C}$ uptake differs strongly. A possible explanation could be the seasonal lifestyle of the foraminifera. In the study of Lintner et al. (2021b) the foraminifera were 


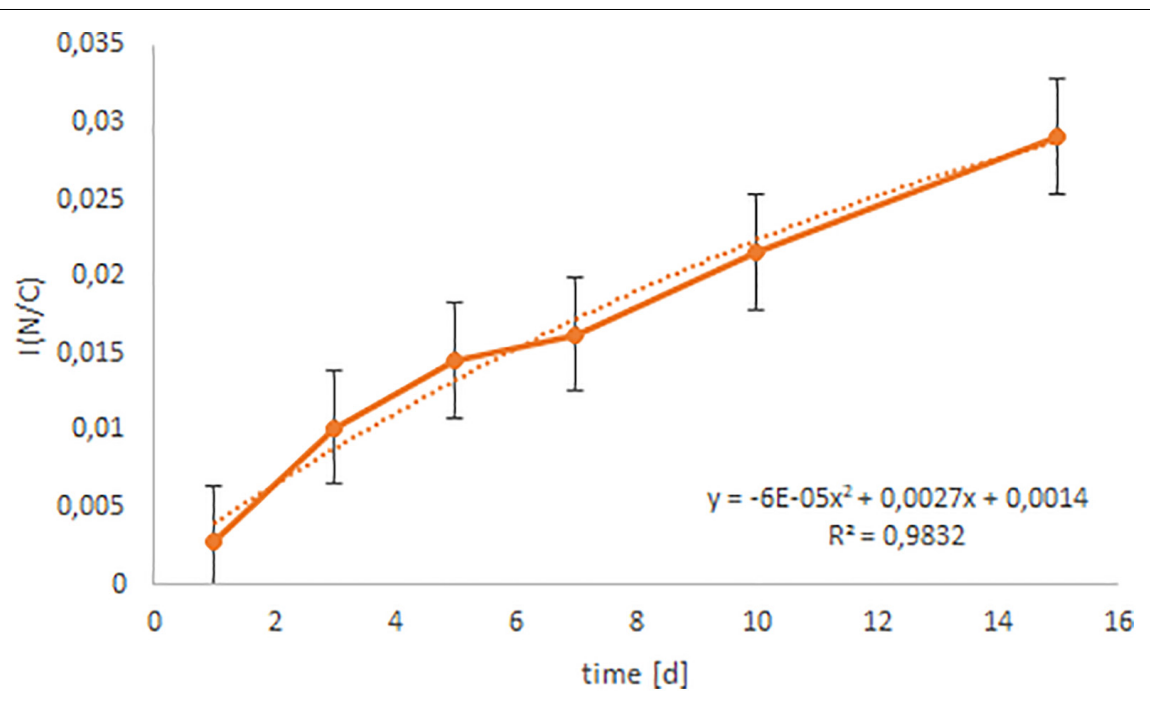

FIGURE 5 | Correlation analysis between $\mathrm{N}$ uptake of $\mathrm{NH}_{4}{ }^{+}$and time. The continuous line represents the generated data of this study, whereas the dotted line represents the ideally calculated trend line.

collected in autumn, whereas the foraminifera in this study were collected in summer. The seasonality of foraminiferal activity in combination with a phytodetrital pulse has been often discussed in literature (e.g., Kitazato et al., 2000). In this study, the population rate of benthic foraminifera was strongly correlated to the deposition of phytodetritus 2 weeks after the phytoplankton bloom which triggers a high reproduction of shallow infaunal taxa (Kitazato et al., 2000).

Isochrysis galbana is a Haptophyte, which occurs naturally in the Baltic Sea (Kaiser et al., 2017). In our experiments I. galbana was definitively not a preferred food source for C. selseyense. A possible explanation could be that I. galbana contains high amounts of fucoxanthine (Kim et al., 2012), which might negatively affect the health of the foraminifera in higher concentrations, but further studies are necessary to clarify this aspect.

Leyanella arenaria is a benthic diatom (Muylaert and Sabbe, 1999) and was an intermediately preferred food source if offered as dried algae. But offered to the foraminifera as a fresh algal diet it was one of the more favorite food sources of $C$. selseyense. This is a quite important result as it shows again that the difference in preference of the same food source depends on the freshness and quality, as in other studies (Lintner et al., 2021b) no significant differences in the food uptake from L. arenaria and D. tertiolecta in a dried form were detected. In our study here, significant differences between the food uptake concerning the tow algal species L. arenaria and D. tertiolecta were observed (Figure 3). Finally, it should be noted that $L$. arenaria is predominantly found on sandy sediments and is not common in silty sediments like at the sampling sites of the Baltic Sea (Sabbe et al., 2010). This suggests that L. arenaria is not a common and often available food source in the natural habitat of $C$. selseyense.

Nannochloropsis salina occurs naturally in the Baltic Sea and showed a high food potential for C. selseyense as an effective carbon source, but considerably lower quality as a nitrogen source
(Figure 1). This alga was the only one which was preferred as dried diet during all experiments (Figure 3). Nannochloropsis salina is quite commonly used in the industry due to the capacity to produce high amounts of fatty acids (Van Wagenen et al., 2012). This content of fatty acids can explain the strong difference between the carbon and nitrogen uptake of the foraminifera, as fatty acids contain much more $\mathrm{C}$ than $\mathrm{N}$ in their molecular structure.

Phaeodactylum tricornutum is a diatom and occurs naturally in the Baltic Sea (Siedlewicz et al., 2020). This alga is not one of the preferred food sources of $C$. selseyense. The fresh algal diet was slightly more preferred at the first day, when dried algal diet uptake was lower. With increasing incubation time, the dried variant was becoming more preferred by the foraminifera.

Finally, it can be stated that the foraminifera C. selseyense prefers generally diatom algae in a dried form (C. calcitrans, $L$. arenaria and $P$. tricornutum) for carbon uptake, but also $N$. salina. For $\mathrm{N}$ uptake from dried algae, the green algae $D$. tertiolecta and P. tricornutum were the preferred food sources. in fresh algal diets the algae C. calcitrans and I. galbana were preferred, especially for longer-term (here 3 days) incubations. This shows the important time aspect of feeding and metabolic activity of foraminifera. Accordingly, not all algae were equally good carbon or nitrogen sources. Focusing on the nitrogen uptake of foraminifera, algae like $D$. tertiolecta or $P$. tricornutum were more suitable than others. Contrary, for carbon nutrition, D. tertiolecta would be a bad choice for this foraminifera and other food sources such as P. tricornutum, I. galbana or N. salina would be more suitable.

\section{Uptake of Dissolved Nitrogen or Carbon}

While at the moment quite a lot is known about the heterotrophic lifestyle of foraminifera (e.g., Moodley et al., 2000), the aspect of inorganic nitrogen assimilation is not that clear. Some studies investigated the ability of foraminifera to store or assimilate 
nitrate in their kleptoplasts (LeKieffre et al., 2018). Our study here suggests a totally new aspect, because the tested foraminifer C. selseyense contains neither kleptoplasts nor photosynthetic symbionts. Therefore, the question arises how this kind of foraminifera is able to use inorganic nitrogen or carbon. During our experiments we observed that $C$. selseyense had a significantly higher $\mathrm{N}$ incorporation of $\mathrm{NH}_{4}{ }^{+}$as $\mathrm{N}$ source compared to $\mathrm{NO}_{3}{ }^{-}$. Other studies showed that the ability to store nitrogen or to assimilate ammonium may be coupled to the presence of kleptoplasts (Jauffrais et al., 2019). Nitrogen uptake via nitrate could be an artifact from contaminating bacteria inside the foraminifera (LeKieffre et al., 2020). LeKieffre et al. (2020) observed structures (prokaryote-like vesicles) in the foraminiferal cell, which were highly enriched with ${ }^{15} \mathrm{~N}$ in contrast to the foraminiferal cytoplasm. This could explain the highly different $\mathrm{N}$ uptake in our experiments. Another aspect deals with the presence of kleptoplasts in some foraminifera. The here investigated foraminifera does not contain any photosynthetic active kleptoplasts (examined with PAM-fluorometry). Past observations of inorganic $\mathrm{N}$ uptake by foraminifera which contain kleptoplasts could lead to the hypotheses, that the uptake of $\mathrm{NO}_{3}{ }^{-}$from the here testes foraminifera could also result from sequestered chloroplasts, which are not photosynthetic active (Grzymski et al., 2002), but further studies are necessary to clarify this aspect at C. selseyense. In contrast to nitrate, ammonium contains "bioavailable nitrogen," which can be subsequently used by endosymbiotic bacteria (Prokopenko et al., 2013), which are often assumed to be present in foraminifera (e.g., Buck and Bernhard, 2001; Tsuchiya et al., 2015; LeKieffre et al., 2020). Based on our study it looks like $\mathrm{N}$ originating from nitrate would not be an acceptable $\mathrm{N}$ source for $C$. selseyense. Some species of foraminifera are able to use $\mathrm{NO}_{3}{ }^{-}$as an alternative electron acceptor in oxygen depleted zones (Glock et al., 2019). Interestingly, foraminifera which live under oxic conditions produce special intracellular proteins, if they are transferred to an anoxic environment (Orsi et al., 2020). This protein synthesis causes a higher nitrogen demand, which may explain that ammonium would be taken up at high rates, when foraminifera are stressed (in our study here the ammonium uptake followed an exponential model). This pattern of course can also be produced just because of $\mathrm{N}$ diffusion into the foraminiferal cytoplasm. However, the possibility for benthic foraminifera to use eucaryotic denitrification pathways in oxygen depleted areas is even genetically determined (Woehle et al., 2018). To clarify this aspect for $C$. selseyense more investigations are necessary, because the here investigated nitrogen uptake was always tested at normal oxygen conditions. to date, it is, however, known that foraminifera without kleptoplasts or symbionts are also able to incorporate inorganic nitrogen into their cells and eventually utilize them as a nitrogen source. Bird et al. (2020) observed that also Ammonia sp., a non-kleptoplast bearing foraminifer, is able to use inorganic nitrogen from ammonium for growth. They also pointed out that Ammonia sp. is not able to assimilate $\mathrm{C}$ from bicarbonate. In our study we could show that $C$. selseyense is able to incorporate $\mathrm{C}$ from bicarbonate (carbonate) into their cytoplasm. Since we dissolved the calcite test and only measured the incorporated $\mathrm{C}$ in the cytoplasm, we can assume that these foraminifera are able to actively incorporate (bi) carbonate into their cells. The studied foraminifera from Bird et al. (2020) were incubated only very short (for a maximum of $20 \mathrm{~h}$ ), which led to no enrichment of ${ }^{13} \mathrm{C}$. Our experiments showed a similar pattern, with minor incorporation until day 7 , followed by a strong increase in inorganic $\mathrm{C}$ uptake. At this point one aspect should be discussed concerning the inorganic $\mathrm{C}$ uptake from foraminifera. In this study we of course used a sterile setup as much as possible, but contamination with bacteria cannot be excluded, since they are inside the cytoplasm of foraminifera or in their test. There existing literature, which showed that Elphidium have bacterial symbionts (Salonen et al., 2019) which can probably also lead to an enrichment of the $\mathrm{C}$ inside the foraminifera. Transmission electron microscopic or NanoSIMS (Nanoscale secondary ion mass spectrometry) studies would help to elucidate inorganic $\mathrm{C}$ uptake and allocation in the foraminifer C. selseyense and its time kinetics. Also, uptake of nitrate as a nitrogen source increased only after day 7. This implies that C. selseyense may change its metabolism after a 1-week starving period (only inorganic compounds, but no organic food source was offered), which allows them to use also bicarbonate or nitrate as $\mathrm{C}$ or $\mathrm{N}$ source.

The capacity of foraminifera to take up and metabolize dissolved glucose is widely known (DeLaca et al., 1981). Foraminifera take up dissolved organic matter though they are classified as suspended particle feeders (DeLaca et al., 1981). In our experiments we could observe that also $C$. selseyense is able to utilize dissolved organic carbon. Goldstein (2003) postulated that glucose and also amino acids are taken up by foraminifera and are rapidly metabolized. Our experiments show that this aspect should be considered more carefully. The uptake of glucose was very low in the first 3 days. This can be an artifact for several reasons. One possible explanation could be that the foraminifera were saturated at the beginning of the experiment. However, this is contradicted by our observation that the foraminifera started feeding on algal diets almost immediately, causing detectable isotope enrichment at day 1. It is also possible that during the experiment bacteria growing inside the dishes became isotopically labeled, which can be digested by the foraminifera. Another point could be that the foraminifera were in a steady state and reduced their metabolism strongly, after placing them from the natural habitat to the crystallization dishes. Nevertheless, after 3 days the uptake of glucose increased rapidly, and then stagnated again (Figure 4). This would underline the theory that foraminifera have steady states where they have a reduced activity. At day 10 the amount of incorporated $\mathrm{C}$ increased sharply again, which would further confirm the steady state theory. Some foraminifera are able to produce cysts (formation of a rigid cell wall around their cytoplasm), which they can use for several things like filter-feeding structures or reproduction (e.g., Alexander and DeLaca, 1987). Cyst building can also be observed in laboratory experiments (Heinz et al., 2005), and it has been assumed that during cyst formation the metabolic activity of foraminifera is decreased (Cedhagen, 1996). This coincidences with our steady state theory, whereas our tested foraminifera were incubated without sediment and no cyst formation could be observed. Summarizing, C. selseyense showed 
a strongly time dependent uptake of dissolved organic matter (here glucose). It seems, that after the uptake of a higher amount of dissolved organic matter the foraminifera fall into a steady state between 3 and 7 days, where they reduce their metabolism.

\section{CONCLUSION}

For this study the food preference of C. selseyense was tested with 6 different algae. Since the uptake of $\mathrm{C}$ and $\mathrm{N}$ is strongly dependent on the offered food source, the choice of algae also depends strongly on the research question (examining $\mathrm{C}$ or $\mathrm{N}$ uptake). The following trends can be derived from the results, which will help to use the optimal food source for future feeding experiments: If algae were offered as a powder, the highest $\mathrm{C}$ uptakes can be expected with C. calcitrans, L. arenaria, $N$. salina and P. tricornutum, whereas D. tertiolecta and I. galbana showed lower $\mathrm{C}$ uptakes. In contrast, highest $\mathrm{N}$ uptakes were recorded for $D$. tertiolecta and $P$. tricornutum. Uptakes by L. arenaria, I. galbana, N. salina and C. calcitrans showed lower values. If algae are offered in fresh form, no clear trend can be recognized after 1 day of feeding. After 3 days, however, a clear preference for $C$. calcitrans can be observed, as well as a slightly preference for $L$. arenaria. In any case, it turns out that $C$. selseyense has a tendency to consume diatoms more than other algae.

On the other hand, the absorption of dissolved organic and inorganic components shows clear preferences. It could be shown

\section{REFERENCES}

Alexander, S. P., and DeLaca, T. E. (1987). Feeding adaptations of the foraminiferan Cibicides refulgens living epizoically and parasitically on the Antarctic scallop Adamussium colbecki. Biol. Bull. 173, 136-159. doi: 10.2307/154 1868

Altenbach, A. (1992). Short-term processes and patterns in the foraminiferal response to organic flux rates. Mar. Micropaleontol. 19, 119-129. doi: 10.1016/ 0377-8398(92)90024-e

Austin, H., Austin, W., and Paterson, D. (2005). Extracellular cracking and content removal of benthic diatom Pleurosigma angulatum (Quekett) by the benthic foraminifera Haynesina germanica (Ehrenberg). Mar. Micropaleontol. 57, 68-73.

Azam, F., Fenchel, T., Field, J., Gray, J., Meyer-Reil, L., and Thingstad, F. (1983). The ecological role of water-column microbes in the sea. Mar. Ecol. Prog. Ser. 10, 257-263. doi: 10.1126/science. 1175309

Beringer, U., Caron, D., Sanders, R., and Finaly, B. (1991). "Heterotrophic flagellates of planktonic communities. their characteristics and methods of study," in The Biology of Free-Living Heterotrophic Flagellates, Vol. 45, eds D. J. Patterson and J. Larsen (Oxford: Clarendon Press), 39-56.

Bird, C., LeKieffre, C., Jauffrais, T., Meibom, A., Geslin, E., Filipsson, H., et al. (2020). Heterotrophic foraminifera capable of inorganic nitrogen assimilation. Front. Microbiol. 11:604979. doi: 10.3389/fmicb.2020.604979

Buck, K. R., and Bernhard, J. M. (2001). "Protistan-prokaryotic symbioses in deepsea sulfidic sediments," in Symbiosis, ed. J. Seckbach (Dordrecht: Springer), 507-517. doi: 10.1007/0-306-48173-1_32

Cedhagen, T. (1996). Foraminiferans as food for Cephalaspideans (Gastropoda: ophisthobranchia), with notes on secondary tests around calcareous foraminiferans. Phuket Mar. Biol. Center Spec. Publication 16, 279-290.

Cesborn, F., Geslin, E., Le Kieffre, C., Jauffrais, T., Nardelli, M. P., Langlet, D., et al. (2017). Sequestred chloroplasts in the benthic foraminifera Haynesina that the glucose uptake does not take place uniformly, which also applies to bicarbonate and nitrate. For further studies, ammonium is the best choice, as the uptake can be described with a clearly defined functional equation and this is valid for the entire experimental process.

\section{DATA AVAILABILITY STATEMENT}

The original contributions presented in the study are included in the article/supplementary material, further inquiries can be directed to the corresponding author/s.

\section{AUTHOR CONTRIBUTIONS}

ML, BL, and SS planned, carried out the experiments, and carried out sampling in the field. ML wrote the manuscript. NK organized the research vessel. WW performed the isotope analysis. PH organized the chemical equipment. All co-authors read the manuscript carefully.

\section{FUNDING}

This work was supported by the University of Vienna: Funding takes place centrally via the OA publishing agreement or via the OA publication fund.

germanica: cellular organization, oxygen fluxes and potential ecological implcations. J. Foraminifer. Res. 47, 268-278.

Chronopoulou, P. M., Salonen, I., Bird, C., Reichert, G. J., and Koho, K. (2019). Metabarcoding insights into the trophic behaviour and identity of intertidal benthic foraminifera. Front. Microbiol. 10:1169. doi: 10.3389/fmicb.2019.01169

Correia, M., and Lee, J. (2000). Chloroplast retention by Elphidium excavatum (Terquem). Is it a selective process? Symbiosis 29, 343-355.

Corzo, A., Morillo, J. A., and Rodriguez, S. (2000). Production of transparent exopolymer particles (TEP) in cultures of Chaetoceros calcitrans under nitrogen limitation. Aquat. Microb. Ecol. 23, 63-72. doi: 10.3354/ame023063

Darling, K., Schweizer, M., Knudsen, K., Evans, K., Bird, C., Roberts, A., et al. (2016). The genetic diversity, phylogeography and morphology of Elphidiidae (Foraminifera) in the Northeast Atlantic. Mar. Micropaleontol. 129, 1-23.

DeLaca, T. E., Karl, D. M., and Lipps, J. H. (1981). Direct use of dissolved organic carbon by agglutinated benthic foraminifera. Nature 289, 287-289.

Dupuy, C., Rossignol, L., Geslin, E., and Pascal, P. Y. (2010). Predation of mudflat meio-macrofaunal metazoans by a calcareous foraminifer, Ammonia tepida (Cushman, 1926). J. Foraminifer. Res. 40, 305-312. doi: 10.2113/gsjfr.40.4.305

Gerlach, S. (1984). Oxygen Depletion 1980-1983 in Coastal Waters of the Federal Republic of Germany, Berichte aus dem Institut für Meereskunde an der Christian-Albrechts-Universität Kiel, 130. Kiel: Institut für Meereskunde Kiel, 97.

Gerlach, S. (1990). Nitrogen, phosphorus, plankton and oxygen deficiency in the German Bright and the Kiel Bay. Kiel. Meeresforschungen Sonderheft $7: 341$.

Glock, N., Roy, A., Romero, D., Wein, T., Weissenbach, J., Revsbech, N. P., et al. (2019). Metabolic preference of nitrate over oxygen as an electron acceptor in foraminifera from the Peruvian oxygen minimum zone. Proc. Natl. Acad. Sci. U.S.A. 116, 2860-2865. doi: 10.1073/pnas.1813887116

Goldstein, S. T. (2003). "Foraminifera: a biological overview," in Modern Foraminifera, Vol. 542, ed. B. K. Sen Gupta (Dordrecht: Springer), 37-55. doi: 10.1007/0-306-48104-9_3 
Gooday, A. J., Levin, L. A., Linke, P., and Heeger, T. (1992). "The role of benthic foraminifera in deep-sea food webs and carbon cycling," in Deep-Sea Food Chain and the Global Carbon Cycle, eds G. T. Rowe and V. Pariente (Dordrecht: Springer), 63-91. doi: 10.1007/978-94-011-2425-2

Grzymski, J., Schofield, O. M., Falkowski, P. G., and Bernhard, J. M. (2002). The function of plastids in the deep-sea benthic foraminifer, Nonionella stella. Limnol. Oceanogr. 47, 1569-1580. doi: 10.4319/lo.2002.47.6.1569

Guillard, R., and Ryther, J. (1962). Studies of marina planktonic diatoms: I Cyclotella nana Hustedt. and Detonula confervacea (CLEVE) Gran. Can. J. Microbiol. 8, 229-239. doi: 10.1139/m62-029

Heinz, P., Geslin, E., and Hemleben, C. (2005). Laboratory observations of benthic foraminiferal cysts. Mar. Biol. Res. 1, 149-159. doi: 10.1080/ 17451000510019114

Jauffrais, T., LeKieffre, C., Schweizer, M., Geslin, E., Metzger, E., Bernhard, J. M., et al. (2019). Kleptoplastidic benthic foraminifera from aphotic habitats: insights into assimilation of inorganic $\mathrm{C}, \mathrm{N}$ and $\mathrm{S}$ studied with sub-cellular resolution. Environ. Microbiol. 21, 125-141. doi: 10.1111/1462-2920.14433

Kaiser, J., Van der Meer, M. T. J., and Arz, H. W. (2017). Long-chain alkenones in Baltic Sea surface sediments: new insights. Org. Geochem. 112, 93-104.

Kim, S. M., Kang, S., Kwon, O., Chung, D., and Pan, C. (2012). Fucoxanthin as a major carotenoid in Isochrysis aff. galbana: characterization of extraction for commercial application. J. Korean Soc. Appl. Biol. Chem. 55, 477-483.

Kitazato, H., Shirayama, Y., Nakatsuka, T., Fujiwara, S., Shimanaga, M., Kato, Y., et al. (2000). Seasonal phytodetritus deposition and responses of bathyal benthic foraminiferal populations in Sagami Bay, Japan: preliminary results from "Project Sagami 1996-1999". Mar. Micropaleontol. 40, 135-149. doi: 10.1016/s0377-8398(00)00036-0

Lee, J., McEnery, M., Pierce, S., Freudenthal, H., and Müller, W. (1966). Tracer experiments in feeding littoral foraminifera. J. Protozool. 13, 657-670.

Lee, J., Price, S., Tentchoff, M., and McLaughin, J. (1961). Growth and physiology of foraminifera in the laboratory: part 1: collection and maintenance micropaleontology. 7, 461-466. doi: 10.2307/1484382

LeKieffre, C., Jauffrais, T., Geslin, E., Jesus, B., Bernhard, J. M., Giovani, M.-E., et al. (2018). Inorganic carbon and nitrogen assimilation in cellular compartments of a benthic kleptoplastic foraminifer. Sci. Rep. 8:10140. doi: 10.1038/s41598-01828455-1

LeKieffre, C., Spero, H. J., Fehrenbacher, J. S., Russell, A. D., Ren, H., Geslin, E., et al. (2020). Ammonium is the preferred source of nitrogen for planktonic foraminifer and their dinoflagellate symbionts. Proc. R. Soc. B Biol. Sci. 287:20200620. doi: 10.1098/rspb.2020.0620

Linke, P., and Lutze, G. F. (1993). Microhabitat preferences of benthic foraminifera a static concept or a dynamic adaptation to optimize food acquisition? Mar. Micropaleontol. 20, 215-234. doi: 10.1016/0377-8398(93)90034-u

Lintner, M., Biedrawa, B., Wukovits, J., Wanek, W., and Heinz, P. (2020). Salinitydepending algae uptake and subsequent carbon and nitrogen metabolisms of two intertidal foraminifera (Ammonia tepida and Haynesina germanica). Biogeosciences 17, 3723-3732. doi: 10.5194/bg-17-3723-2020

Lintner, M., Lintner, B., Wanek, W., Keul, N., and Heinz, P. (2021a). The effect of the salinity, light regime and food source on carbon and nitrogen uptake in a benthic foraminifer. Biogeosciences 18, 1-12.

Lintner, M., Lintner, B., Wanek, W., Keul, N., Von der Kammer, F., Hofmann, T., et al. (2021b). Effects of Heavy Metals (Pb, Cu, Zn) on Algal Food Uptake by Elphidium Excavatum (Foraminifera), (under review).

Moodley, L., Boschker, H. T., Middelburg, J. J., Pel, R., Herman, P. M., De Deckere, E., et al. (2000). Ecological significance of benthic foraminifera: $13 \mathrm{C}$ labelling experiments. Mar. Ecol. Prog. Ser. 202, 289-295. doi: 10.3354/meps2 02289

Muylaert, K., and Sabbe, K. (1999). Spring phytoplankton assemblages in and around the maximum turbidity zone of the estuaries of the Elbe (Germany). the Schelde (BelgiumlThe Netherlands) and the Gironde (France). J. Mar. Syst. $22,133-149$.

Myklestad, S., and Haug, A. (1972). Production of carbohydrates by the marine diatom Chaetoceros affinis var. Willei (Gran) Hustedt. I. Effect of the concentration of nutrients in the culture medium. J. Exp. Mar. Biol. Ecol. 9, $125-136$.

Nikulina, A., Polovodova, I., and Schönfeld, J. (2007). Environmental response of living benthic foraminifera in Kiel Fjord, SW Baltic Sea. eEarth Discuss. 2, 191-217. doi: 10.5194/eed-2-191-2007
Orsi, W., Morard, R., Vuillemin, A., Eitel, M., Wörheide, G., Milucka, J., et al. (2020). Anaerobic metabolism of Foraminifera thriving below the seafloor. ISME J. 14, 2580-2594. doi: 10.1038/s41396-020-0708-1

Polovodova, I., and Schönfeld, J. (2008). Foraminiferal test abnormalities in the Western Baltic Sea. J. Foramin. Res. 38, 318-336. doi: 10.2113/gsjfr.38.4.318

Prokopenko, M. G., Hirst, M. B., Brabandere, L. D., Lawrence, D. J., Berelson, W. M., Granger, J., et al. (2013). Nitrogen losses in anoxic marine sediments driven by Thioploca-anammox bacterial consortia. Nature 500, 194-198. doi: $10.1038 /$ nature12365

Sabbe, K., Vanelslander, B., Ribeiro, L., Witkowski, A., Muylaert, K., and Vyverman, W. (2010). A new genus, Pierrecomperia gen. nov., a new species and two new combinations in the marine diatom family Cymatosiraceae. Vie Milieu Life Environ. 60, 243-256. doi: 10.1080/0269249x.1997.9705418

Salonen, I. S., Chronopoulou, P. M., Bird, C., Reichart, G. J., and Koho, K. A. (2019). Enrichment of intracellular sulphur cycle-associated bacteria in intertidal benthic foraminifera revealed by $16 \mathrm{~S}$ and aprA gene analysis. Sci. Rep. 9:11692. doi: 10.1038/s41598-019-48166-5

Schmidt, C., Geslin, E., Bernhard, J. M., LeKieffre, C., Rogenberger, H., Marianne, S. M., et al. (2021). Feeding Experiments of the Seep-Associated Foraminifer Nonionella labradorica With a Marine Methanotrophic From the Arctic, EGU General Assembly 2021. EGU21-14673, Vienna. doi: 10.5194/egusphere-egu2114673.

Schönfeld, J., and Numberger, L. (2007). Seasonal dynamics and decadal changes of benthic foraminiferal assemblages in the western Baltic Sea (NW Europe). J. Micropalaeontol. 26, 47-60. doi: 10.1144/jm.26.1.47

Schwarzer, K., and Themann, S. (2003). Sediment distribution and geological buildup of Kiel Fjord (Western Baltic Sea). Meyniana 55, 91-115.

Senocak, T. (1995). Schwermetalluntersuchung an Fischen der deutschen Ostseeküste (Kliesche, Limanda limanda; Flunder, Platichthzs flesus; Hering, Clupea harengus und Dorsch, Gadus morhua). Ber. Inst. Meereskunde ChristianAlbrechts Univ. Kiel 270:177.

Shimeta, J. (1993). Diffusional encounter of submicrometer particles and small cells by suspension feeders. Limnol. Oceanogr. 38, 456-465. doi: 10.4319/lo.1993.38. 2.0456

Siedlewicz, G., Żak, A., Sharma, L., Kosakowska, A., and Pazdro, K. (2020). Effects of oxytetracycline on growth and chlorophyll a fluorescence in green algae (Chlorella vulgaris), diatom (Phaeodactylum tricornutum) and cyanobacteria (Microcystis aeruginosa and Nodularia spumigena). Oceanologia 62, 214-225. doi: 10.1016/j.oceano.2019.12.002

Suhr, S. B., Alexander, S. P., Gooday, A. J., Pond, D. W., and Bowser, S. S. (2008). Trophic modes of large Antarctic Foraminifera: roles of carnivory, omnivory, and detritivory. Mar. Ecol. Prog. Ser. 371, 155-164. doi: 10.3354/meps07693

Tantanasarit, C., Englande, A. J., and Babel, S. (2012). Nitrogen, phosphorus and silicon uptake kinetics by marine diatom Chaetoceros calcitrans under high nutrient concentrations. J. Exp. Mar. Biol. Ecol. 446, 67-75. doi: 10.1016/j. jembe.2013.05.004

ter Jung, C. (1992). Beitrag zum Schwermetallgehalts-Monitoring (Yn, Cd, $\mathrm{Hg}, \mathrm{Cn}$, $\mathrm{Ag}, \mathrm{Pb}, \mathrm{Cr}, \mathrm{Ni})$ in Miesmuscheln an der Schleswig-Holsteinischen Ostseeküste (1988-1989), Vol. 221. Kiel: Berichte aus dem Institut für Meereskunde an der Christian-Albrechts-Universität Kiel, 89.

Tsuchiya, M., Toyofuku, T., Uematsu, K., Brüchert, V., Collen, J., Yamamoto, H., et al. (2015). Cytologic and genetic characteristics of endobiotic bacteria and kleptoplasts of Virgulinella fragilis (Foraminifera). J. Eukaryot. Microbiol. 62, 454-469. doi: 10.1111/jeu.12200

Van Oevelen, D., Soetaert, K., Middelburg, J. J., Herma, P. M. J., Moodley, L., Hamels, I., et al. (2006). Carbon flows through a benthic food web: integration biomass, isotope and tracer data. J. Mar. Res. 63, 453-482. doi: 10.1357/ 002224006778189581

Van Wagenen, J., Miller, T. W., Hobbs, S., Hook, P., Crowe, B., and Huesemann, M. (2012). Effects of light and temperature on fatty acid production in Nannochloropsis salina. Energies 5, 731-740. doi: 10.3390/en5030731

Woehle, C., Roy, A., Glock, N., Wein, T., Weissenbach, J., Rosenstiel, P., et al. (2018). A novel eukaryotic denitrification pathway in foraminifera. Curr. Biol. 28, 2536-2543. doi: 10.1016/j.cub.2018.06.027

Wukovits, J., Enge, A., Wanek, W., Watzka, M., and Heinz, P. (2017). Increased temperature causes different carbon and nitrogen processing patterns in two common intertidal foraminifera (Ammonia tepida and 
Haynesina germanica). Biogeosciences 14, 2815-2829. doi: 10.5194/bg-14-28152017

Conflict of Interest: The authors declare that the research was conducted in the absence of any commercial or financial relationships that could be construed as a potential conflict of interest.

Publisher's Note: All claims expressed in this article are solely those of the authors and do not necessarily represent those of their affiliated organizations, or those of the publisher, the editors and the reviewers. Any product that may be evaluated in this article, or claim that may be made by its manufacturer, is not guaranteed or endorsed by the publisher.

Copyright (c) 2021 Lintner, Lintner, Wanek, Schmidt, Keul and Heinz. This is an open-access article distributed under the terms of the Creative Commons Attribution License (CC BY). The use, distribution or reproduction in other forums is permitted, provided the original author(s) and the copyright owner(s) are credited and that the original publication in this journal is cited, in accordance with accepted academic practice. No use, distribution or reproduction is permitted which does not comply with these terms. 


\section{APPENDIX}

TABLE A1 | Statistical evaluation (algae classified based on multiple range test-Tukey HSD test) of the feeding preference for different dried algal species.

\begin{tabular}{lll}
\hline Algae & pC & pN \\
\hline Chaetoceros calcitrans & $\mathrm{B}$ & $\mathrm{C}$ \\
Dunaliella tertiolecta & $\mathrm{A}$ & $\mathrm{D}$ \\
Isochrysis galbana & $\mathrm{A}$ & $\mathrm{BC}$ \\
Leyanella arenaria & $\mathrm{C}$ & $\mathrm{A}$ \\
Nannochloropsis salina & $\mathrm{C}$ & $\mathrm{AB}$ \\
Phaeodactylum tricornutum & $\mathrm{BC}$ & $\mathrm{D}$ \\
\hline
\end{tabular}

The significant groups are described with letters. The same letter indicates the same homogeneous group.

TABLE A2 | Statistical evaluation of the fresh vs. powder algae feeding experiments. Significant values are in bold.

\begin{tabular}{|c|c|c|c|c|c|}
\hline Algae & Isotope & Time & Mean square & F-ratio & $p$-value \\
\hline \multirow{2}{*}{ Chaetoceros calcitrans } & C & 3 & 0.011538 & 7.62 & 0.051 \\
\hline & $\mathrm{N}$ & 3 & 0.004054 & 38.47 & 0.003 \\
\hline \multirow[t]{3}{*}{ Dunaliella tertiolecta } & $\mathrm{C}$ & 1 & 0.000226 & 3.16 & 0.150 \\
\hline & $\mathrm{C}$ & 3 & 0.000195 & 4.45 & 0.102 \\
\hline & $\mathrm{N}$ & 3 & 0.000147 & 0.5 & 0.520 \\
\hline \multirow[t]{4}{*}{ Isochrysis galbana } & C & 1 & 0.000028 & 1.24 & 0.327 \\
\hline & C & 3 & 0.000021 & 0.51 & 0.516 \\
\hline & $\mathrm{N}$ & 1 & 0.000014 & 0.35 & 0.586 \\
\hline & $\mathrm{N}$ & 3 & 0.000099 & 9.41 & 0.037 \\
\hline Leyanella arenaria & C & 1 & 0.004769 & 8.43 & 0.044 \\
\hline \multirow[t]{4}{*}{ Nannochloropsis salina } & C & 1 & 0.007175 & 55.07 & 0.002 \\
\hline & C & 3 & 0.006410 & 9.98 & 0.034 \\
\hline & $\mathrm{N}$ & 1 & 0.000093 & 54.39 & 0.002 \\
\hline & $\mathrm{N}$ & 3 & 0.000049 & 2.00 & 0.230 \\
\hline \multirow[t]{4}{*}{ Phaeodactylum tricornutum } & C & 1 & 0.000111 & 0.83 & 0.413 \\
\hline & C & 3 & 0.000159 & 1.48 & 0.290 \\
\hline & $\mathrm{N}$ & 1 & 0.000008 & 0.92 & 0.393 \\
\hline & $\mathrm{N}$ & 3 & 0.000028 & 1.51 & 0.287 \\
\hline
\end{tabular}

